\title{
AUTOBIOGRAPHIES OF MACEDONIAN REFUGEES
}

\author{
by Anna Kurpiel
}

\section{Introduction}

Recently, in Poland, a number of anthropological and historical works have been written based on 'oral histories' or biographical narratives induced through an interview (cf. inter alia Włodarek \& Ziółkowski, 1990; Engelking, 1994; Czyżewski, Piotrowski \& Rokuszewska-Pawełek, 1996; Kurkowska-Budzan, 2009; Filipkowski, 2010). However, less interest is taken in written autobiographies issued in print, often in very limited editions, to satisfy the needs of family, friends, organizations and associations. During the research for my doctoral dissertation, dedicated to Macedonian refugees, ${ }^{1}$ I encountered people who published their autobiographies as books and I would like to take a closer look at such texts in this paper.

Autobiographies of Macedonian refugees are unknown to a wider audience, just like the whole issue of Macedonian emigration from the time of the Greek Civil War. Aegean Macedonia, one of the parts of Macedonia, is the region of the Balkans that was the last to be liberated from the Turkish occupation. As a result of the Balkan wars it was incorporated by Greece, forming its northern province. Then, the autochthonous Slavic population living in this area-the Macedonians-became the largest ethnic minority in northern Greece, occupying mainly the Kosturski and Lerinski regions. During the Greek Civil War, which lasted from 1946

1 The Ph.D. thesis entitled Macedońscy uchodźcy wojenni w Polsce: Adaptacja, migracje, pamięć (Macedonian War Refugees in Poland: Adaptation, Migration, Memory), was written under the supervision of professor Krzysztof Ruchniewicz and defended at the Institute of History at the University of Wrocław in 2012. 
to 1949 , partly voluntarily, partly under duress, the Macedonians joined the communist Greek guerrilla militias stationed in the mountain areas of the Aegean Macedonia.

The first wave of emigration from Greece took place in 1948 and embraced only children younger than sixteen years of age. The official reason for the expulsion was shielding the children from the turmoil of the war and, in particular, intensifying bombing. Children under the care of young women, the so-called majki ('mothers') and guerrillas, crossed on foot the mountain border between Greece and Yugoslavia, and then were sent by train from Yugoslavia, following the earlier agreement concluded with the communist parties of different countries, to the then Eastern bloc countries-Romania, Bulgaria, Poland, East Germany, Czechoslovakia and Hungary.

In 1949, the Greek communists lost the war, which resulted in another wave of emigration, this time mainly consisting of the adult population. As a result of the conflict between Stalin and Tito, Yugoslavia closed the border for the Greek communists supporting Stalin, and that made the Greeks and Macedonians flee to Albania, and next sail to Poland, the Soviet Union (Tashkent), and other countries of the Central and Eastern Europe. In total, until 1950, Poland accepted 3,015 children and 9,282 adults from Greece (Wojecki, 1989). Later, this number changed due to the ongoing migration of refugees (for instance the family reunification action pursued by the Red Cross). According to the data cited by Arkadiusz Słabiga (2008), in 1955, there were 15,215 Greek refugees in Poland, including 7,410 Macedonians, 7,357 Greeks and 448 Koutsovlachos, but the latter often declared that they were Greeks.

Since the return to Greece and more specifically to the Aegean Macedonia for many years was impossible, the Macedonians emigrated from Poland to the Yugoslav Republic of Macedonia, as well as Bulgaria, Canada and Australia. This resulted in a significant decrease in the number of Macedonian refugees in Poland and the disappearance of organizations associating them. Today, the Macedonians who in 1948 were children are now elderly. I interviewed some of them and I got most of the autobiographies included in my analysis from them.

\section{Dimensions of Autobiographical Learning about Oneself and the World}

Written autobiographies, as opposed to induced biographical interviews, are created at the initiative of the author himself/herself. Therefore, they are closer to memoirs written of one's own accord, and not for a competition, 
but unlike them they are a collection of memories selected by the author, often situated-for a better understanding-in a broader perspective of a given historical time and the fate of the community. However, just as in the case of biographical interviews, the present imposes here the way of talking about the past and its interpretation. At the same time, such memories as noted by Antonina Kłoskowska make "global flashback and reconstruction of the author's life" (after Żurko, 2003, p. 128), and show the life of the author in whole or in large parts of it. This type of autobiographies can be and is a source of scientific analysis-historical, because they contain a description of the specific reality of the past, sociological and anthropological-focusing on the analysis of the experiences of particular individuals, ways of writing about their own lives, models of selfcreation, etc.

In this article, I would like to take an anthropological perspective to look at autobiographies in terms of their motifs (not always explicit), their origin and the function they perform in the lives of the authors and the community. I am pursuing answers to two questions: 'Why would someone decide to take the effort of autobiographical work, the result of which is a published book?' and 'What is such an autobiography for the author and for a wider group of stakeholders?'

These motifs and functions relate to three complementary dimensions. Firstly, autobiographies may be an attempt to talk about painful experiences, written 'for oneself' when they take the form of a self-analysis with a strong therapeutic color. Secondly, autobiographies are a result of the need to tell the story of an individual for the sake of the present reference groups, co-existing acquaintances and future generations. Thirdly, autobiographies become the 'glue' of a group often transnational in nature; they are written for a given community, immersed in the concrete world of meanings, serving specific type of communication.

\section{Autobiographies as an Attempt to Tell about Painful Experiences (Writing for Oneself)}

This is probably the most recognized theme related to writing an autobiography, which-understood as a specific 'cleansing tool'-becomes the object of analysis of sociologists, anthropologists and psychologists. The process of creating an autobiography is combined with an attempt to reconcile with and organize the difficult past. This approach is presented by, among others, Wiesław Theiss (2007), dealing with the history of the "wandering children" from the army of General Anders, i.e. a group very similar to the young Macedonians expelled en masse from northern Greece. Theiss calls autobi- 
ographies, memoirs, diaries, letters and the like literary pieces the "texts of life." According to him, the authors try to answer the question: 'Who am I?', the question appearing when talking about the broken identity, inability to cope with the childhood trauma, the situation of emigration, etc.

The cathartic aspect of autobiographical writings is based on the need for expression, which Duccio Demetrio (2000) explains in his book, Autobiografia: Terapeutyczny wymiar pisania o sobie (Autobiography: Therapeutic Dimension of Writing about Oneself), as follows: "In everyone's life, there comes a moment when an overwhelming desire is born to tell about one's life in a different way than usually. Similar feelings are evoked, sooner or later, in each of us-this experience is shared both by women and men, and, above all, those grown in the culture of the West. The desire to tell about oneself has been felt by human beings for hundreds of years, probably starting from the moment in which writing as a creative act took the form of stories about life, told in the first person, with the intention of saving specific experiences and sensations from falling into oblivion" (p. 9).

The drive for autobiographical expression, according to the Italian researcher, depending on the circumstances, sometimes is "the necessity, duty, or even imperative, but at the same time the right" (ibid.). Interestingly, Demetrio sees in the effort of self-reflection an educational travel rather than the final summary of life.

\section{Autobiographies and the "Biographical Necessity" (Writing for Oneself and for Others)}

Taking up autobiographical work is also related to another phenomenon, namely the "biographical necessity." This term, originally developed by Gabriele Rosenthal, has been successfully adapted into Polish social studies by Kaja Kaźmierska (1996). Generally speaking, in the outlined context, the narrative necessity boils down to a compulsion to share ones experiences linked with the awareness of having participated in important events. In the case of research conducted by Kaźmierska, it was the experience of World War II, put in the form of border land narratives, and in the case of Macedonian children it was the displacement, refuge and the dramatic events related to them.

Autobiographers following their narrative necessity see themselves as witnesses to history, and treat their story as a testimony passed on to future generations, including obviously their families. The story is treated here as an important part of the mission, and the biographer is elevated to the rank of a self-appointed hero-guard of the tradition threatened with disintegration. 
One of the aspects of biographical narrative necessity is, as noted by Kaźmierska, "a particular story of the space, which the narrators are close to" (ibid., p. 98). In the case of the Aegean Macedonians, a call for stories manifests itself not only in the form of autobiographies or memoirs, but all kinds of texts tackling the homeland problem. This is due to the particular situation of Aegean Macedonia, which since 1913 has been a part of Greece. In spite of the fact that most Macedonians are of the opinion that Aegean Macedonia in terms of the cultural and moral aspects is no different from Vardar Macedonia (now the Republic of Macedonia), the gap between these two areas is continually emphasized. The Aegean Macedonia is a contested, multicultural, tragic, and even dangerous land. At the same time, it is longed for and dreamed about.

\section{Autobiographies as the 'Glue' of the Group}

An autobiography, though written by one person, is the work about a certain community and for a certain community-nation, ethnic group, generation, etc. The primary manifestation of it is the collective 'I' occurring in the autobiographical narrative. Although narrators describe an individual story, they are aware that it is also, and sometimes primarily, collective history-for example of Macedonians born in northern Greece in the 1930s and 1940s, and even more broadly-all Aegean Macedonians who share their wandering fate.

Fania Martinowa-Bučkowa, in her semi-autobiographical work, declares, "I want to write in my book about this generation of children, their dignity, that they are Macedonians, and that their homeland is called Macedonia, about children, who, although dispersed over many countries in the world remain faithful to the order of their teacher and their ancestors: carry Macedonia in your hearts and love it" (Martinowa-Bučkowa, 1998, pp. 12-13). In another work, also prepared by Aegean Macedonians, we read as follows: "How have we sinned, God, that you have given us such fate [...]. What makes us different from those who were born in Bitola, [a city in the Republic of Macedonia-A.K.] why are we disconnected?" (Profilovski \& Bojačev, 1998, p. 10).

In both quoted passages we can see an irresistible urge-expressed more or less explicitly-to tell not only about oneself, but about all those who experienced and survived the same things as the narrators. Martinowa-Bučkowa determines her own reference group as the "generation of children," and Profilovski and Bojačev leave no doubts as to who are these 'we' by consistently using the first person plural. 
Written and published autobiographies are also of purely practical value. They make a real connection of Macedonian children that during the Greek Civil War had to leave their homeland and now are scattered throughout the world. It is no longer just an area of memory or collective identity, people mentally present in the books, but also a real object, having a symbolic meaning. At the Society of Aegean Macedonians "Nezaborav" in Skopje, we can find almost in every autobiography, nay, every work written by Aegean Macedonians.

It often happens that the issuance of an autobiography is completed with the help of Macedonian friends residing in other countries-mostly in Canada. The materials needed for the development of books keep flowing from numerous places. The goal of these publications is enhancing the transnational community of Aegean Macedonians and providing a point of reference and identification for individual refugees.

\section{Nemirno vreme and Pożegnanie z ojczyzna as Examples of Autobiographical Literature Elaborated by Refugees}

Throughout the last two decades, Macedonian refugees have prepared dozens of autobiographical works in the form of classic autobiographies as well as collections of short stories and poems. Because of the research area, limited to the Republic of Poland and the Republic of Macedonia, I got acquainted only with a part of them, most of which are works written by people I have interviewed. Among the books published in Poland it is worth mentioning: Kokardy z powojennych tasiemek (Bows with Postwar Ribbons) by Józef Wyspiański (2004), Pożegnanie z ojczyzna (Farewell to the Homeland) by Spiro Gagaczowski (2007) and Prom do raju (Ferry to Paradise) by Nicole Nascova (2000). As for the texts in the original language-I have already mentioned I nije sme deca na majkata zemja (I my jesteśmy dziećmi naszej matki ziemi, And We are also Children of our Mother Earth) by Fania MartinovaBučkova (1998), Istrkalan Kamen (Toczacy się kamien,, Rolling Stone) by Vasilka Geogrievska-Bandevska (2003), Otidoa so vetrot (Przeminęło z wiatrem, Gone with the Wind) written by her husband, Jane Bandevski (2003) and Nemirno vreme (Niespokojny czas, Restless Time) by Hristo Ristovski (2011). Two of the above-mentioned works deserve special attention because of their representativeness of the species, namely: Pożegnanie z ojczyzna by Spiro Gagaczowski and Nemirno vreme by Hristo Ristovski.

Their authors during the civil war and political emigration were still children. Spiro Gagaczowski came to Poland as a twelve-year-old boy, married a Polish woman and decided to settle here. He currently lives in Lubin and is a trained chemist. Hristo Ristovski came to Poland from 
an orphanage in Czechoslovakia. He graduated from a high school with a pedagogical profile in Jelenia Góra and then began studying at the Polish Studies in Opole. After the first year at the university, he was brought to Skopje, where he graduated from the local university, majoring in history, and where he has lived to this day.

Both autobiographers, in our conversations, shared with me their insights concerning their creative work. One of the topics discussed by us concerned the reasons why they took up autobiographical work.

In the case of Gagaczowski, the idea of writing an autobiography arose in part accidentally and in part was inspired by the earlier literary efforts of his colleague-Józef Wyspiański who told the story of himself and his Macedonian wife in the book Kokardy z powojennych tasiemek (2004). Nevertheless, Spiro acknowledges that the ultimate impulse to delve into the personal recollections appeared relatively recently:

And so you do not remember these things... and who then would have thought that once someone will have an idea at all to tell or write or whatever. Five years ago, I was not thinking about any writing, about my book, and so on and memories and so on. ${ }^{2}$

The immediate motivation for his elaborating the literary revelations was provided by the questions from the grandchildren and children stimulating the future author to reflection:

Well, a little bit, I mean my kids already knew a little, but the grandchildren began to ask: and what is that, once they heard me talking in Macedonian with my brother. What language do you speak, what's the language of your talking?

In the Introduction to Pożegnanie z ojczyzna we read about the obligation to save the traces of the past from sinking into oblivion. Still vivid images of the loss of the old house make the narrator try to rely on his own memory and the memories of his loved ones in order to reconstruct and maintain the identity essence:

I decided to try to save a little something from those years from total oblivion. I gathered some materials. I looked into several books. I ordered in my head the memories passed on to me by my father and siblings and I contained them in this elaboration. (Gagaczowski, 2007, pp. 5-6)

Gagaczowski then adds:

2 All quotations from the utterances of the interviewed Macedonians (passages highlighted in the main text in italics) are derived from the interviews that I conducted in Poland and in the Republic of Macedonia in the period 2009-2011. 
With this book and all the memories comprised in it I wanted to say goodbye to my place of birth, to my homeland. (ibid., p. 6)

The trace of the farewell to the homeland (probably contained in the title for a reason!) is de facto a kind of a final reconciliation with fate-expressed by an expatriate, refugee, sentenced to life away from the country where he was born. In many cases, also of the Macedonians from Greece, this phase never comes, and the yearning for the place lost is permanently stronger than the cleansing (in the spirit of Demetrio) 'saying goodbye' to it.

The autobiography of Spiro Gagaczowski explicitly manifests the biographical narrative necessity; it is a testimony given primarily to younger generations of the dispersed family of the Aegean Macedonians:

I sincerely hope that the younger generations of our large family will become interested in the book, that they, in the age of computers, mobile phones, in the era of pursuing material goods, will notice in it the values that should be cultivated and protected. (ibid., p. 6)

Pożegnanie z ojczyzna is a complete piece of literature and-most likely-will remain the only literary attempt of the author. The situation is quite different in the case of Hristo Ristovski who has elaborated a number of publications (mostly memories or poems). His writing necessity was revealed quite early, while he was staying in an orphanage in Czechoslovakia; his flair for writing, carefully nurtured after arriving in Poland, resulted in, among other things, patriotic poems (see, inter alia, Ristovski, 2005), but the extensive autobiographical narratives-Nemirno vreme among them-were written much later.

Niespokojny czas is not really an autobiography in the strict sense, since it does not try to show the entire life of the author, and only the selected parts-life in his village (Utracone dziecinstwo, Ch. Lost Childhood), school years in Poland (Zapiski ze Szczecina, Ch. Records from Szczecin) and then the first year of studies, a travel to Skopje and consequences related to it (Wracanie do wolnej Macedonii, Ch. Returning to Free Macedonia). In Nemirno vreme, there is no introduction from the author. Instead, there is a short preface prepared by Jancze Andonovski, Ristovski's friend. The memories have been published in Macedonian and English, most likely to broaden the readership with the persons who do not have the command of the Macedonian language-presumably the families of the Macedonians living in Canada or Australia.

During one of our meetings, Hristo meticulously explained:

Now, I will give you this book because it is very important. I have described how I left Greece, I describe how we learned Greek... why we escaped from there. 
That is, I describe everything: how old I was, as we learned [...] And now here: Record from Szczecin. That means: Notes from Szczecin, describing it: what it was like in Szczecin. How long we were there, who was there, we were there with the Greeks. That we lived well with them. We were buddies-not as they say! That we had brawls-it's not like this! We were pals!

The cited paragraph shows a clear desire to prevent the dissemination of false images created after many years. Due to the contemporary Macedonian policy in relation to the Macedonian-Greek conflict, aroused around the country's name and national emblems, past events in the life of those remaining in exile are interpreted in a specific way by the refugees themselves. A good example is provided by the past relationship between the Greek and Macedonian children in the orphanages in Poland. Against this background, Ristovski-acting as a participant in these events-feels obliged to pass on the 'truth.'

As in the case of the work discussed above, in Niespokojny czas, the pronoun 'we' is intertwined with ' $\mathrm{I}$ '-and the collective memories are combined with the personal ones. Here also are contained detailed descriptions of individual experiences, supported by photographs and letters-specific souvenirs from Poland performing the documentative and informative function (intended primarily for other Macedonian emigrants). From between the lines, we can read out the experience of the refugee community, opened in the motto from the author:

Wherever we went, we were forced to respect the social norms there. But, we managed to survive. (Ristovski, 2011, p. 3)

and closed in Zakończenie (Conclusion):

During my entire life someone told me to be: a Greek, a Czech, a Polish, a Yugoslavian, etc. And I became what others want me to be. I respected the laws and norms prevailing at that time in the given societies. Just as I was forced to do so, so were 9,000 Macedonian children expelled from Aegean Macedonia. However, we still remained the Macedonians, no one else. Above all, the most important thing for us was our Macedonian character. Therefore, a philosophical thought has always accompanied me: no nation without a past has a future. (ibid., pp. 30-31)

Both books, Pożegnaniezojczyzną and Nemirnovreme are known, which is worth noting, among the Aegean Macedonians scattered across many countries, and their authors have become symbolic landmarks, the guardians of memories and history. 


\section{Autobiographies and Narrative Interviews: Final Methodological Reflection}

Autobiographies, which I have tried to outline, are certainly an interesting research material, which has already been argued by such classics as Florian Znaniecki and William I. Thomas (Thomas \& Zaniecki, 1918). It is worth noting, though, that autobiographies treated not as an independent source, but as complementary one to other interview-related research techniques often pose serious methodological problems. The decision to cooperate with the Interlocutor, who is also an autobiographer, requires research vigilance and must be supported by a high degree of methodological awareness. The fact that such person has written an autobiography strongly affects the course of the conversation. The stories told by interviewees-autobiographers differ significantly from the reflection spun by people 'uncontaminated' with pen-work. The tales growing out of autobiographical 'background' are smoothed, subordinated to the chronology of events, devoid of standstills, moments of being lost in thought and slips, and told 'more nicely.' It also happens that someone who once became an autobiographical writer, remains then only him/her, 'trapped' by his/her own text, and somehow loses the natural ability of narration. This is how it turned out to be in the following cases:

I got everything there in these stories [...]! I will not talk about it. It is there [in the book-A.K.].

Nicole Nacov

And I was included in the last round. So that... in nineteen forty... on the twelfth... anyway here it is written in the book [...]. This means there the grandfather, the whole family, except my sister and brother, who were left in... for such reasons there, in the book it is written [...]. In the neighboring village, two months we were there, and how it was when agitators and so on and so on... here it is in the book everything described as it proceeded [...]. It says everything in the book. Read the book and we'll talk.

Spiro Gagaczowski

How many years we lived there, Józek? How many? I do not remember...

It is in the book.

Risa and Józef Wyspiańscy 


\section{References}

Bandevski, J.M. (2003). Otidoa so vetrot. Skopje.

Czyżewski, M., Piotrowski, A., \& Rokuszewska-Pawełek, A. (Eds.). (1996). Biografia a tożsamość narodowa. Łodź: Katedra Socjologii Kultury Uniwersytetu Łódzkiego.

Demetrio, D. (2000). Autobiografia: Terapeutyczny wymiar pisania o sobie. (O. Czerniawska, Pref.; A. Skolimowska, Trans.). Kraków: Oficyna Wydawnicza Impuls.

Engelking, B. (1994). Zagłada i pamięć. Warszawa: Wydawnictwo Naukowe PWN.

Filipkowski, P. (2010). Historia mówiona i wojna: Doświadczenie obozu koncentracyjnego w perspektywie narracji biograficznych. Wrocław: Wydawnictwo Uniwersytetu Wrocławskiego.

Gagaczowski, S. (2007). Pożegnanie z ojczyzną. Lubin.

Geogrievska-Bandevska, V. (2003). Istrkalan Kamen. Skopje: Kitano.

Kaźmierska, K. (1996). Konstruowanie narracji o doświadczeniu wojennej biografii: Na przykładzie analizy biografii kresowych. In M. Czyżewski, A. Piotrowski, \& A. Rokuszewska-Pawełek (Eds.), Biografia a tożsamość narodowa (pp. 85-103). Łódź: Katedra Socjologii Kultury Uniwersytetu Łódzkiego.

Kurkowska-Budzan, M. (2009). Antykomunistyczne podziemie zbrojne na Białostocczyźnie: Analiza wspótczesnej symbolizacji przeszłości. Kraków: Towarzystwo Wydawnicze Historia Iagellonica.

Martinova-Bučkova, F. (1998). I nije sme deca na majkata zemja. Skopje.

Nascov, N. (2000). Prom do raju. Opole.

Profilovski, L., \& Bojačev, A. (1998). Poslednij Ďid. Skopje: UPA Enterprise C.O.

Ristovski, H. (2011). Nemirno vreme. Skopje: Prosvetno Delo.

Ristovski, H. (2005). Spomeni. Skopje: DASU Boro Petruševski.

Słabig, A. (2008). Aparat bezpieczeństwa wobec mniejszości narodowych na Pomorzu Zachodnim w latach 1945-1989. Szczecin: Instytut Pamięci Narodowej Oddział w Szczecinie.

Theiss, W. (2007). W poszukiwaniu siebie: Poetyckie wspomnienia tułaczego dziecka. In D. Lalak (Ed.), Migracja, Uchodźctwo, Wielokulturowość: Zderzenie kultur we wspótczesnym świecie (pp. 169-190). Warszawa: Wydawnictwo Akademickie Żak. 
Thomas, W.I., \& Znaniecki, F. (1918). The Polish Peasant in Europe and America: Monograph of an Immigrant Group, Vol. I-V. Boston: Richard G. Badger/The Gorham Press.

Włodarek, J., \& Ziółkowski, M. (1990). Metoda biograficzna w socjologii. Warszawa - Poznań: Wydawnictwo Naukowe PWN.

Wojecki, M. (1989). Uchodźcy polityczni z Grecji w Polsce, 1948-1975. Jelenia Góra: Karkonoskie Towarzystwo Naukowe.

Wyspiański, J. (2004). Kokardy z powojennych tasiemek. Lubin.

Żurko, J. (2003). O Pożytkach badania tożsamości narodowej metodą autobiograficzną. In I. Szlachcicowa (Ed.), Biografia a tożsamość (pp. 124-152). Wrocław: Wydawnictwo Uniwersytetu Wrocławskiego. 